\title{
The Custody Question and Child Neglect Rehearings
}

Every child neglect case forces the judicial system to balance its concern for the welfare of the child against the rights of the parent. Not surprisingly, the tension between the child's well-being and the parent's rights leads to inconsistencies in the law and in its application. However, needless confusion has arisen from the current practice of treating all custody questions, including both divorce and neglect, alike, rather than constructing a rule responsive to the demands of the child neglect cases. The problems are acute when parents petition for return of children previously found neglected. After discussing the statutory "neglect" threshold and the "best interests" and "unfitness" standards, applied in general to custody disputes, this comment will suggest an approach to parental petitions for the return of neglected children.

\section{The Neglect Threshold}

The "neglect"1 threshold is the central feature of the American statutory scheme: it is the finding of "neglect" which authorizes the court $^{2}$ to take temporary custody of the child from the parent. ${ }^{3}$ Though there are few clear rules to guide the court in determining if a child is

1 The terms "dependency" and "neglect" are sometimes used interchangeably in discussion of the statutes by commentators. In many states, however, a "dependent" child is one whose parents fail properly to care for him solely because of poverty, whereas a "neglected" child is one whose parents, though financially able to provide adequate care, do not. E.g., Conn. Gen. STAT. ANN. \& 17-53 (1958). In other jurisdictions, the term "dependent" alone is used to describe what this comment calls a "neglected" child; and in some states, the neglected child is termed "dependent and neglected." See, e.g., KaN. GeN. Stat. ANN. § 38-802(g) (1963). For the purposes of this discussion, a "neglected" child will be one who, by reason of parental action, condition, or omission, is deprived of the intellectual, moral, emotional, or physical environment necessary to produce a competent adult citizen. No child whose physical environment is inadequate because of parental poverty will be considered "neglected."

2 The neglect law is generally administered by the juvenile court (with limited concurrent jurisdiction in the "family court" in some states); procedure is in most cases unlike either civil litigation or criminal proceedings. See Simpson, The Unfit Parent: Conditions Under Which a Child May be Adopted Without the Consent of his Parent, 39 U. DET. L.J. 347 (1962), and UNIForm Chind Cusrody ACT (lst tentative draft 1966).

3 The language of the statutes in a few states does not explicitly require a finding of "neglect" or "dependency" to authorize transfer of custody, but the statutory formulations in those states effectively impose the neglect threshold on the neglect hearings, and such statutory ambiguities are often remedied by decisional law. 
"neglected," certain specific conditions constituting neglect are listed in most statutes: frequent or persistent presence of the child in a place of "ill repute" or "evil associations," complete abandonment by the parent, ${ }^{5}$ dangerous employment or occupation of the child, ${ }^{6}$ physical injury or abuse of the child by the parent. ${ }^{7}$ The statutory definitions, however, lean heavily on more ambiguous criteria: the child is neglected if the parents fail to provide either such physical and medical care "as is required by law" or is otherwise necessary,, ${ }^{8}$ or such parental care as is "necessary for the child's health, morals, and well-being," or if by reason of parental "neglect, cruelty, or depravity" the child's home is an "unfit or improper place" for him.10 And the courts often rely on "general grounds" rather than any precise finding when they find children neglected.11 The apparent common element in these various definitions of neglect lies in the principle that the state may justifiably intervene in the child's behalf if his parents have failed to provide a minimum level of protection and care..$^{12}$ If the court judges the child to be neglected, it then faces the question of custody. In all states, a neglect finding authorizes the court to transfer temporary custody of the child to a child welfare agency for placement in a private home or in a public institution. ${ }^{13}$ But the majority rule explicitly states that the parent retains the right to permanent custody, and may later petition for return of the child on grounds that the offending defects in the home environment have been cured. ${ }^{14}$ It is these later petitions with which this comment is concerned.

4 Conn. Gen. Stat. ANN. § 17-53 (1958).

5 E.g., ARK. Stat. ANn. § 45-203(b) (1964).

B ARIz. Rev. StAT. ANN. \& 8-2014(f) (1956).

7 IND. ANN. STAT. \& 9-2807 (1956).

8 Mo. ANN. STAt. § 211.031(a) (1966). A few states, Missouri included, exempt parents who deny certain medical care to their children on religious grounds from the operation of the neglect statutes.

9 IDAHO CODE ANN. \& 16-1625(l)(2) (Supp. 1967).

10 AlA. Code tit. 13, § 350 (1958); N.H. Rev. Stat. ANN. § 169.2 I (1965).

11 See, e.g., In re Morrison, 144 N.W.2d 97, 103-04 (Iowa 1966).

12 In re Vikse, 147 Mont. 417, 421-22, 413 P.2d 876, 878 (1966). The "minimum" acceptable standard is not precisely defined, partly because the inherently imprecise notions of humaneness and decency intrude. But any environment in which the child is unlikely to acquire the intellectual and social tools necessary to productive adulthood is presumably unacceptable.

13 The court may, alternatively, leave the child with the parents, under the supervision of a social worker, probate officer, or child welfare agency. Some statutes, and many cases, state a policy in favor of leaving the child with the parent whenever feasible. Als. Cons tit. 13, § 361 (1958); DEL. CODE ANN. tit. 10, §§ 902, 1102 (1953); In re Mathers, 371 Mich. 516, 533-34, 124 N.W.2d 878, 885-86 (1963); In re J.L.L., 402 S.W.2d 629, 634 (Mo. 1966) (dicta); In re Sweet, 317 P.2d 231, 235 (Okla. 1957); In re State, 17 Utah 2d 349, 411 P.2d 839 (1966).

14 A small minority of state statutes apparently permit termination of parental rights 


\section{Operation of the Custody Meghanism: The "BEST INTERESTS" Rule}

The courts in many states are directed by the neglect statutes to look to the "best interests and welfare" of the child in choosing a temporary custodian. ${ }^{15}$ In others, the statutes merely list the various choices made available to the court by the neglect finding. ${ }^{16}$ Subsequent petitions by the parents for return of custody are apparently to be decided according to the general custody law of the jurisdiction, absent statutory mention of the "best interests" test. ${ }^{17}$

The "best interests" formula is applied in the majority of jurisdictions whenever temporary custody is in issue; in states which follow this standard, courts apparently do not discriminate among types of custody disputes, but impose the "best interests" test on all situations from divorce decrees to neglect cases. ${ }^{18}$ The rule provides that the court in assigning custody balance the parental environment directly against the available alternatives. An alternative environment need only be judged significantly more conducive to the child's welfare and best interests to sustain a transfer of custody away from the parents. ${ }^{19}$

without a finding of unfitness. E.g., CoLo. Rev. Stat. ANN. § 22-1-6(c) (1963); VA. CodE ANN. § 16.1-178 (1960).

15 This is the case in Alabama, Arizona, Connecticut, Colorado, Delaware, Georgia, Hawaii, Idaho, Indiana, Louisiana, Massachusetts, Montana, Nevada, New Jersey, North Carolina, Pennsylvania, South Dakota, Virginia, Washington, West Virginia, Wyoming, and the District of Columbia. In addition, the "best interests" formula is read into the statutes by judicial determination in some states. E.g., Bregar v. Seymour, 74 Ill. App. 2d 197, 219 N.E.2d 265 (1966); Hendricks v. Curry, 401 S.W.2d 796, 801 (Tex. 1966).

16 E.g., KAN. GEN. STAT. ANN. § 38-824(b) (1965).

17 The statutes do not explicitly incorporate the general custody law into the neglect cases; but it is apparently generally assumed by courts and commentators alike that there is no "special" custody rule for neglect cases, once temporary custody has been taken from the parent under the neglect statute. Idaho, however, specifies that the "best interests" test is to be applied at custody rehearings. IDAfo CODE ANN. § 16-1638 (1967).

18 See Bregar v. Seymour, 74 I1l. App. 2d 197, 216 N.E.2d 265 (1966); Hendricks v. Curry, 401 S.W.2d 796 (Tex. 1966); Wendland v. Wendland, 29 Wis. 2d 145, 138 N.W.2d 185 (1965). Simpson, supra note 2, disagrees as to the general custody rule when parent and nonparent compete for custody; but see cases cited in Halstead v. Halstead, 144 N.W.2d 861, 864-65 (Iowa 1966). Sources which hold the "unfit parent" standard to be the general rule rely largely on old cases. E.g., Kay \& Philips, Poverty \& the Law of Child Custody, THE LAw OF THE POOR 393-94 (J. tenBroek ed. 1966). The "best interests" test is now apparently the dominant rule, though quite a few jurisdictions still formally follow the "unfit parent" doctrine. See, e.g., B. Armstrong, 2 California family Law 993-94 (Supp. 1966). Confusion as to the rule followed is compounded by the courts, which often state both the "best interests" and "unfit parent" rules as governing law in the course of a single opinion, as in In re Guardianship of C., - N.J. Super. -, 237 A.2d 652, 662, 664 (Juv. \& Dom. Rel. Ct. 1967), where the court states the "unfit parent" rule as a "public policy" of the jurisdiction, but concludes that the custody question turns on the "best interests" issue.

19 Giacopelli v. The Crittenton Home, 16 Ill. 2d 556, 158 N.E.2d 613 (1959) (maj. opin- 
Painter v. Bannister ${ }^{20}$ is a recent and well-publicized case illustrating the effect of the "best interests". rule. In this instance, custody of the child had been voluntarily transferred by the father to the child's maternal grandparents upon the death of the mother in an auto accident; the grandparents refused to return the child to the father after he remarried, and he brought an action in habeas corpus to regain custody. Here, there was no adjudication of neglect and no showing that the father had been or was likely to become a neglectful parent. Furthermore, the court specifically found the father and his present wife fit to have the child. ${ }^{21}$ Nonetheless, concluding that the "stable, conventional, middle-class, middle-west" 22 environment afforded by the grandparents would better serve the child's welfare than the "[greater] freedom of conduct ... [and the] opportunity to develop his individual talents"23 afforded by the parent, the court refused to allow the father to resume custody.

The Painter case illustrates how the "best interests" formula may operate when applied as a general custody rule to the parent's petition for return of custody. ${ }^{24}$ If the rule may work this harshly in cases where the parent is untainted by any history of neglect one would certainly not expect more generous treatment of a formerly neglectful parent when he petitions for return of custody.

In Commonwealth $v$. Ball, ${ }^{25}$ the parents of a child previously found neglected petitioned for return of custody; they argued that they were the rightful custodians of the child if the court found that the conditions constituting neglect had been changed, and that there was little likelihood of future neglect if the child were returned to them. The Supreme Judicial Court of Massachusetts, affirming the lower court's denial of the petition, held:

Even if the cause stated for the original commitment no longer exists and the parents are now competent and fit to have the care of the child, the court may, in the exercise of a wise discretion and upon an impartial determination of the facts in a particular case, decide that the welfare of the child will not permit her removal from her present custody. ${ }^{26}$

ion); Kouris v. Lunn, 257 Iowa 1267, 1271-72, 136 N.W.2d 502, 505 (1965); Jones v. Sutton, 388 S.T.2d 596, 598 (Ky. 1965).

20258 Iowa 1390, 140 N.W.2d 152 (1966).

21 Id. at 1393, 140 N.W.2d at 154.

$22 I d$.

23 Id.

24 The Michigan, Nebraska, California, and New York rules definitely do not follow this formulation. See notes $35-38$ infra and accompanying text; note 18 supra.

25259 Mass. 148, 156 N.E. 21 (1927).

$28 I d$. at 151,156 N.E. at 22. 
In the original custody proceedings, the court had to be convinced that "neglect" was present and that the "best interests" of the child were served in its removal from the parent. In the custody rehearing, however, the parent must establish not only that he can provide a proper environment for the child, but also that the home environment would be "better for" the child than the current temporary one. The original "neglect threshold" has been depressed: it is far more difficult for the parent to regain the child than it was to resist loss of custody. The threshold is lowered both in the test applied at rehearing and in the shift of the burden of persuasion to the parent.

The heavy burden carried by the parent in petitioning for return of custody is increased by certain factors peculiar to the neglect problem. Child welfare departments, for example, may be particularly opposed to returning the child to a parent formerly found neglectful. These agencies often initiate the original neglect proceedings, and they can hardly be expected to deal disinterestedly with cases in which they once acted as moving party. ${ }^{27}$ In addition, most juvenile courts have no independent source of expert psychological and sociological analysis, and thus must rely on the child welfare agencies for specialized advice. ${ }^{28}$ The agencies may have similar investigating and consulting duties in other types of custody cases, but only in neglect proceedings

27 See In re Sweet, 317 P.2d 231, 233 (Okla. 1957); Sommers v. Sommers, 33 Wis. 2d 22, 28-29, 146 N.W.2d 428, 431 (1966), for examples of this tendency. Under certain circumstances, the interests of the parent may conflict directly with those of the agency involved, as when the case worker feels his judgment challenged by the rehearing proceedings. See In re Mathers, 371 Mich. 516, 124 N.W.2d 878 (1963), for an instance of the extent to which parent and agency can clash. The child welfare agencies are quite often the complainants in neglect cases. See Kay \& Philips, supra note 18, at 409. R. Mulforo, V. WXLEGALA \& F. MELSON, CASEWORKER \& JUdGe IN NEGLECT CASES (1956), a sort of combat manual for the caseworker in court, is indicative of the attitude of the agency in juvenile court.

28 For discussions of the inadequate current utilization of expert information, see Foster \&. Freed, Child Custody, 39 N.Y.U.L. REv. 423, 441 (1964); Skolnik, Psychiatric Evidence in Child Custody Proceedings, 22 N.Y.U. INTRA. L. REv. 154 (1967); Walker, Measuring the Child's Best Interests, 44 DENver L.J. 132 (1967). Cook County, Illinois, is atypical in that the juvenile court has its own psychiatric consultants. About one-third of the juvenile judges have no probation and social work staff available to them, and eighty to ninety per cent have no available psychological or psychiatric consultant. McCane, Profile of THE NATION's Juvenile Court JUdGes (monograph of the Center for the Behavioral Sciences at George Washington University, 1965). Three-fourths of the judges devote less than one-quarter of their time to juvenile matters-thus most of them cannot be said to be "specialists" by experience in juvenile cases, much less in the problems of neglect cases. It has been said that "good will, compassion and similar virtues are . . . admirably prevalent throughout the system [of juvenile courts] . . . . But expertise, the keystone of the whole venture, is lacking." Note, Juvenile Delinquents: the Police, State Courts, and Individualized Justice, 79 HARv. L. REv. 775, 809 (1966). This discussion deals directly with the delinquency question, but is relevant as an examination of the qualifications of the juvenile judge to deal with neglected children as well. 
are they likely to appear both as interested party and as agent of the court. In marked contrast, the litigating parties in divorce custody battles will arrive in court before any children's aid society or probation officer becomes involved in the case.

Furthermore, in neglect cases the legal resources of the parents cannot be expected to match those of the agency's representative, who is often experienced in the workings of the juvenile court and has access to competent counsel. ${ }^{29}$ Environmental neglect cases typically involve parents who have minimal financial and educational resources, ${ }^{30}$ and who are therefore less likely to seek and get good legal representation. In other classes of custody disputes, the child welfare agency may be called on for expert advice, but the contestants are usually individuals -if not the two parents, typically a parent and a near relative of the child-more likely to be evenly matched than in the neglect cases. ${ }^{31}$ Thus in neglect cases the child welfare agency has systematic in-court advantages often not balanced by any force committed to the interests of the parent.

Statements of the "best interests" rule often mention a presumption that the child's best interests are realized when the parent has custody. ${ }^{32}$ But this presumption is of uncertain force at best, and in any case is rebuttable. ${ }^{33}$ In the neglect context, where the parent who petitions

29 Thus, R. Mulford, V. Wylegala \& F. Melson, Caseworker \& Judge in Neglect Cases (1956), in its fourth printing in 1964, is a thoroughgoing trial practice manual for the caseworker, with techniques for compiling evidence, preparing a case, and presenting it effectively.

30 Conclusive evidence is not available; but see Kay \& Philips, supra note 18, at 410-11. With the possible exception of physical abuse cases, most neglect cases involve parents from low-income, culturally deprived environments; the neglect law, as one authority puts it, is directed toward the poor, Paulsen, Juvenile Courts, Family Courts, \& the Poor Man, THE LAW OF THE POOR 370 (J. tenBroek ed. 1966).

31 Of course, mismatches, either in financial resources or legal representation or both, may occur, and doubtless sometimes do, when two individuals come into court. But the neglect law alone has a built-in disparity in the relative strengths of the typical opponents; divorce cuts across economic lines, and in general ex-spouses and relatives should be reasonably well-matched. The neglect statutes of many jurisdictions are silent as to parental counsel; the statutes which do mention counsel for the parents provide that the judge may at his discretion arrange for (or permit) the presence of an independent legal advisor either for the parent or for the child. The present trend is toward counsel for the child in juvenile delinquency cases. In re Gault, 387 U.S. 1 (1967). But as yet no similar movement for neglect proceedings has developed. Paulsen, supra note 30 , at 379.82 , states an argument for use of counsel in juvenile court cases as a whole.

32 E.g., Kouris v. Lunn, 257 Iowa 1267, 1271, 136 N.W.2d 502, 505 (1965).

33 See Painter v. Bannister, 258 Iowa 1890, 140 N.W.2d 152 (1966); Halstead v. Halstead, 144 N.W.2d 861 (Iowa 1966); McKay v. Mitzel, 137 N.W.2d 792 (N.D. 1965); Belisle v. Belisle, 27 Wis. 2d 317, 134 N.W.2d 49l (1965); and Note, Fit Parent May be Deprived of Custody, 4 Houston L. REv. 131 (1966), which argues that Painter overturns the parental preference doctrine. In $M c K a y$, the parental preference is called a "right to primary consideration," subordinate to the best interests of the child; the content of "primary con- 
for return of custody must carry the double burden of persuasion on the issues of neglect and best interests, the presumption cannot offer much comfort: the court has in the original neglect hearing already overcome whatever parental preference it recognizes, and taken the child from the parent. The parent must now convince the court that return of custody is justified. . $^{34}$

\section{The Unfit Parent: The Alternative Gustody Rule}

The "best interests" rule is not the guiding principle in every jurisdiction when parent contends with nonparent for custody of the child. In some states the parent must be held "unfit" to care for the child if temporary custody is awarded to the nonparent. ${ }^{35}$ Thus in Kropp $v$. Shepsky, ${ }^{36}$ a habeas corpus proceeding brought by the mother of an infant child against the current custodians (who had previously attempted to adopt the child), the New York Court of Appeals stated the rule:

Except where a nonparent has obtained legal and permanent custody of a child by adoption, guardianship or otherwise, he who would take or withhold a child from mother or father must sustain the burden of establishing that the parent is unfit and that the child's welfare compels awarding its custody to the nonparent. . . . [The] burden rests, not, for instance, upon the mother to show that the child's welfare would be advanced by being returned to her, but rather upon the nonparents to prove that the mother is unfit to have her child and that the latter's well-being requires its separation from its mother. ${ }^{37}$

This "unfitness" threshold, which governs temporary custody dispositions in some of the states, is a statutory requirement for perma-

sideration" is not developed, but the court here declined to give the preference the force of presumption. 137 N.W.2d at 794.

34 It is a general maxim of custody law that the party who seeks to alter a prior award of (temporary) custody must show such significant change in the previous situation that the child's best interests are served by a change in custody.

35 In re Mathers, 371 Mich. 516, 124 N.W.2d 878 (1963); Raymond v. Cotner, 175 Neb. 158, 120 N.W.2d 892 (1963); People ex rel. Kropp v. Shepsky, 305 N.X. 465, 113 N.E.2d 801 (1953); People v. Talbot Perkins Adoption Serv. 46 Misc. 2d 369, 259 N.Y.S.2d 440 (Spec. Term. 1965). According to B. Armstrong, 2 California Family Law 993 et seq. (Supp. 1966); California still follows rigorously this "unfit parent" rule.

36305 N.Y. 465,113 N.E.2d 801- (1953).

37 Id. at 469,113 N.E.2d at 804 . See also People ex rel. Portnoy v. Strasser, 303 N.Y. 539, 104 N.E.2d 895 (1952); Ball ఛ: Ball, 180 Neb. 145, 141 N.W.2d 449 (1966); People ex rel. Conti v. Molinari, 23 App. Div. 2d 898; 260 N.Y.S.2d 551 (1965). 
nent and final denial of custody to the parent in most jurisdictions. The question of permanent custody arises in connection with the severing of the legal parent-child relationship, a prerequisite to adoption without consent of the natural parent. ${ }^{38}$

No rigid standards of parental fitness with regard to the temporary custody question are provided in the cases following this rule. Parents have been found "unfit" to have custody by reason of continuing emotional instability, ${ }^{30}$ and it seems to be the rule that an immoral pattern of conduct will establish unfitness, ${ }^{40}$ although adultery alone may not. ${ }^{41}$ Disparity in physical environment is immaterial unless conditions in the parental home are such as to be "harmful to the child." 42 Rehabilitation and prospective behavior are emphasized when the parent's past conduct has been unsatisfactory. ${ }^{43}$ Drunkenness ${ }^{44}$ and criminal conviction $^{45}$ may establish unfitness for custody, depending on circumstances in the case.

The statutes concerned with permanent custody or termination of all parental rights offer little help in defining the "unfit" parent; there are not even any partial listings of conditions presumptive of "unfitness" comparable to those provided for "neglect." 4 Cases dealing with the question of permanent custody, though ambiguous, are somewhat more useful. "Immorality," adultery (usually amounting to promiscuity), cruelty, abandonment, and "neglect" are common grounds for judgments of unfitness. ${ }^{47}$ Emotional instability of the parent and ex-

38 Statutory formulations vary. Seventeen states explicitly mention "termination of parental rights," eight of which specify separate hearings on the termination issue alone. In others, adoption statutes require a finding of "abandonment" by or "unfitness" of the natural parent. Some states apparently demand only a finding of neglect before a guardian for adoption may be appointed, though decisional law has imposed the "unfitness" standard in many of these latter jurisdictions.

39 Veseth v. Veseth, 147 Mont. 169, 174, 410 P.2d 930, 932 (1966); Belisle v. Belisle, 27 Wis. 2d 317, 320-21, 134 N.W.2d 491, 493-4 (1965).

40 E.g., Sommers v. Sommers, 33 Wis. 2d 22, 146 N.W.2d 428 (1966).

41 E.g., Jones v. Sutton, 388 S.W.2d 596 (Ky. 1965); M- L- v. M- R-, 407 S.W.2d 600, 604 (Mo. App. 1966); Wendland v. Wendland, 29 Wis. 2d 145, 138 N.W.2d 185 (1965). 42 People ex rel. Kropp v. Shepsky, 305 N.Y. 465, 113 N.E.2d 801 (1953); People ex rel. Portnoy v. Strasser, 303 N.Y. 539, 104 N.E.2d 895 (1952).

43 Foster \& Freed, Child Custody, 39 N.Y.U.L. Rev. 423 n.50 (1964); cf. id. at n.53.

44 M- L- v. M- R-, 407 S.W.2d 600, 602 (Mo. App. 1966); People ex rel. Kropp v. Shepsky, 305 N.Y. 465, 113 N.E.2d 801 (1953); People ex rel. Portnoy v. Strasser, 303 N.Y. 539, 104 N.E.2d 895 (1952); Wendland v. Wendland, 29 Wis. 2d 145, 138 N.W.2d 185 (1965).

45 Foster \& Freed, supra note 43, 428 n.21.

46 E.g., KaN. GEN. STAT. ANN. § 38-824(b) (1965).

47 See Simpson, supra note 2, at 355, for a list of cases; see generally Lincoln, Judicial Considerations in Child Care Cases, 11 WAYNe L. REv. 709 (1965), for problems of application of the unfitness standard. 
treme marital discord have also been held to constitute unfitness, with consequent permanent denial of custody to the parent. ${ }^{48}$

Self-rehabilitation by the parent, present conditions, and future probabilities, not past conduct, are emphasized in permanent custody questions. ${ }^{49}$ In Fritts $v$. Krugh, ${ }^{50}$ involving a habeas corpus petition by rather unsavory parents for custody of two of their children, then living with prospective adoptive parents, the Michigan Supreme Court discussed the statutory requirements for disposition of permanent custody (terminating parental rights) as opposed to temporary custody:

Here, we find the legislative intent plainly set forth in the use of the words "temporary" and "permanent." In accordance with that legislative intent, we hold that, while evidence of temporary neglect may suffice for entry of an order taking temporary custody, the entry of an order for permanent custody due to neglect must be based upon testimony of such a nature as to establish or seriously threaten neglect of the child for the long-run future. ${ }^{51}$

Thus there are two common elements underlying the various fact situations in cases dealing with both temporary and permanent custody, when parents are deemed unfit: a history of severe and continuous neglect and the high probability of future deprivation of the child if returned to the parent. ${ }^{52}$ Basically, an "unfit" parent is one whom the court concludes cannot or very probably will not meet the minimum standards of responsibility imposed by the neglect threshold..$^{53}$

48 E.g., In re J.L.L., 402 S.W.2d 629 (Mo. App. 1966).

49 In re Vikse, 147 Mont. 417, 413 P.2d 876 (1966); In re Sweet, 317 P.2d 231 (Okla. 1957).

. 50354 Mich. 97, 92 N.W.2d 604 (1958).

51 Id. at 114,92 N.W.2d at 613.

52 See Lincoln, supra note 47, at 711; Note, Infants-Termination of Parental Rights, 14 U. KAN. L. REv. 117 (1965).

53 The same notion of unfitness is apparently employed in termination of rights (neglect and adoption) cases and custody disputes, where the custody rule of parental fitness is applied at all. An exception to this identity of treatment occurs on occasion when a court, though unable to find the parent unfit enough to order termination of the parentchild relationship (or to deny the parent temporary custody on "unfitness" grounds), nonetheless awards custody to the party seeking adoption, on the grounds that custody may be given to one who has kept the child for an extended time with permission of the parent. See Simpson, supra note 2, at 358. As to this "voluntary relinquishment" doctrine, see People ex rel. Conti v. Molinari, 23 App. Div. 2d 893, 260 N.Y.S.2d 551 (1965). But see Gordon v. Gordon, 317 Mass. 771, 59 N.E.2d 5 (1945); Bottoms v. Carlz, 310 Mass. 29, 36 N.E.2d 379 (1941); Raymond v. Cotner, 175 Neb. 158, 120 N.W.2d 892 (1963); People ex rel. Kropp v. Shepsky, 305 N.Y. 465, 113 N.E.2d 801 (1953); and at least in recent years, when custody is thus given to persons who have long cared for the child, courts have tended to explain their decisions directly in "best interests" terms. Painter v. Bannister, 258 Iowa 1390, 140 N.W.2d 152 (1966); Kouris v. Lunn, 257 Iowa 1267, 136 N.W.2d 502 
The concept of parental fitness, applied to neglect cases when the parent petitions for return of custody, neutralizes some, but by no means all, of the special handicaps faced by the parent under the "best interests" doctrine. ${ }^{54}$ For example, the influence of the child welfare agency is circumscribed by the shift in the burden of proof and by the higher threshold used to measure parental conduct and home environment. The agency continues to function as an important source of information and expert advice, but its reports are tested against the central issue, the assessment of the child's future environment in the custody of the parent. The burden shift and the higher proof threshold is of particular benefit to the parent not adequately represented by counsel. The problem of the agency as an interested party is not, of course, completely solved, but the higher threshold of parental misconduct and the shift in the burden of persuasion mitigate possible agency bias.

Because the concept of the unfit parent looks toward the future, it is more closely adapted to the real question put in issue by the parent's petition for return of custody. The central fact of the rehearing is that the parent no longer has custody: the neglect concept is thus not directly applicable to the present situation and merely draws the court back to contemplation of past circumstances. ${ }^{55}$ And the notion of "best interests" provides no direction at all for the inquiry. The concept of parental fitness requires the court to make an explicit judgment of the child's prospective environment if returned to the parent. ${ }^{36}$

Though the parental fitness standard avoids some of the flaws inherent in the "best interests" rule, it does not provide an appropriate

(1965); McKay v. Mitzel, 137 N.W.2d 792 (N.D. 1965); Rosson v. DeArman, 323 S.W.2d 75 (Tex. Civ. App. 1959).

54 See notes 27-34 and accompanying text supra.

55 See In re Sweet, 317 P.2d 281 (Okla. 1957).

56 The concept of the "unfit parent" provides a more precisely delimited standard for examining the effects of parental conduct than does the notion of "best interests and welfare" of the child. The court should be encouraged to consider every espect of the behavior of the parents and the potential effect of the home environment on the child, but the "best interests" formula provides no framework for organizing this mass of data and reducing it to a decision. See Giacopelli v. The Crittenton Home, 16 Ill. 2d 556, 56768, 158 N.E.2d 613, 614 (1959) (concurring opinion). For examples of dubious decisions, in which "neglect" was found in large measure on the basis of the parents' unorthodox religious views, see Hunter v. Powers, 206 Misc. 784, 135 N.Y.S.2d 371 (Dom. Rel. Ct. N.Y.C. 1954); In re Watson, 95 N.Y.S.2d 798 (Dom. Rel. Ct. N.Y.C. 1950); and In re Black, 3 Utah 2d 315, 283 P.2d 887 (1955). Paulsen, supra note 30, at 383-86, deals with situations in which juvenile courts have abused the similarly wide discretion of the law of juvenile delinquency. The "parental preference" or "presumption" attendant to the "best interests" rule cannot guide the court's investigation even if it is given weight, for the "presumption" only tells the court which way to decide if other things are equal, not how to discover and evaluate those "other things." 
device for deciding whether the neglected child should be returned to the parent. Use of the unfitness standard would raise the threshold for denial of temporary custody to the level required for termination of all parental rights. But the issues presented in temporary custody dispositions are fundamentally different from those involved in termination of the parent-child relationship.

In deciding temporary custody, the court investigates the prospective home environment resulting from immediate return of the child to the parent; in dealing with the question of permanent custody and termination, the court inquires if the home environment is hopeless. Application of the same legal standard to these different issues would tend to confuse the temporary custody problem with that of permanent custody. Such a trend would be unlikely to benefit the parent. Juvenile courts genuinely committed to aiding the neglected child, if forced to choose between returning the child to a currently inadequate environment and finding the parent unfit, might often take the latter course. And a parent found unfit in a hearing dealing with temporary custody would be hard put to resist a charge of unfitness in a subsequent petition for termination of parental rights.

Moreover, the unfitness concept is simply not designed to deal with the temporary custody question. The unfitness test is well-adapted to the straight-forward cases, in which it is either obvious that the child would not suffer from being returned to the parent, or clear that the parent is incapable of rehabilitation. But in the close cases, where the parental environment is in transition, a more flexible standard is required. Thus in In re Vikse,,$^{57}$ the Montana Supreme Court overruled an order declaring a two-year old child dependent and neglected and awarding permanent custody to the petitioning child welfare agency. ${ }^{58}$ Here, the child was temporarily in the custody of foster parents. The mother had a history of emotional disturbance, including extensive institutional care, and at the time of the hearing her prognosis was uncertain. The father had previously been financially unable to care for the child, but at the time of hearing had secured construction work and made initial efforts to find a suitable home and adult supervision for the child during his absences at work. The father was also considering a consent divorce which would enable him to remarry and establish a stable family relationship for his son. The court discussed

57147 Mont. 417, 413 P.2d 876 (1966).

58 In Montana, permanent custody questions are dealt with in "dependency and neglect" petitions, MONT. REv. Codes ANN. § 10-510 (1957), although as this case demonstrates, permanent custody depends essentially on a judgment of parental unfitness. 
the father's continuing efforts to establish an adequate environment, and concluded that:

The problems and difficulties attending the Vikse family are multiple and have not been completely removed. Other considerations beyond the scope of this appeal ... justify continuing observation and supervision over the situation. [The neglect statute] permits the court to return custody of children to the parents when the conditions of dependency have been removed, and the court may order such custody upon whatever conditions or supervision is deemed necessary under the facts of the case..$^{59}$

The Montana court, forced to read a great deal into the neglect statute to reach this result, clearly arrived at the correct solution: the father was not prepared to resume custody immediately, but the situation was fluid enough to prevent foreclosing future return of the child.

Thus neither of the general custody rules is suitable for adjudging parental petitions for return of neglected children. The "best interests" formulation does not direct the court's inquiry and puts a massive burden of persuasion on the parent. The "unfit parent" standard does not cut finely enough to deal with the critical cases.

\section{An Approachi to a Neglect Case Custody Rule}

The neglect case custody question, unlike other custody disputes, is not fundamentally an adversary proceeding. Other custody problems, following from divorce actions or voluntary custody transfers by the parent with subsequent refusal of the custodian to return the child, ${ }^{60}$ are litigated between two or more parties, each of whom seeks custody of the child. But in the neglect case, the child is removed from the parent by action of the court, and the parent petitions that court for return of custody. ${ }^{61}$

Certain problems inherent in other custody proceedings are not rele-

50147 Mont. at 423, 413 P.2d at 879. See Kline, The Validity of Long-Term Foster Family Care Service, 44 CHILD WeLfare 185 (1965), in which it is argued that long-term foster care not involving total separation from the parent is in general the optimum treatment for the child who must be taken from the family.

60 The latter situation is illustrated by the Painter case. The current trend is toward minimizing the effects of the adversary contest. See UNIFors Chind Custody Acr (Ist Tent. Draft 1966). But whatever the procedure, the underlying contest between parties cannot be prevented.

61 Of course, a contest may develop between the parent and the temporary custodian; but placement with private persons is usually made by the child welfare agency which is the official temporary custodian, and thus the clash is typically between the agency and the parent, as in the Vikse and Mathers cases. 
vant in these special circumstances. ${ }^{62}$ The question of forum-shopping is meaningless in the neglect case, wherein the forum is fixed by the original neglect hearing. The relitigation of issues settled in the prior proceedings, often the object of attempts to modify custody decrees in divorce cases, is in one sense the entire purpose of the neglect rehearing: the parent seeks to show that the conditions amounting to neglect have been cured, so it is pointless to think in terms of safeguarding the finality of the earlier decision. Finally, there is here no question of harassment of one party by the other through the medium of the custody dispute-the court has taken the child from the parent, and it is hardly harassment of the court for the parent to petition for return of custody.

But neglect cases, though free of some of the problems of other custody disputes, have dilemmas of their own. Placement-either temporary or permanent—of the child who is taken from the parent is the most immediate problem. Neglected children are not typically the "blue-ribbon children which agencies wish to place for adoption." 63 One lawyer involved in neglect cases maintains that it is very difficult to place Caucasian children more than four or five years old for adoption, and almost impossible to find adoptive parents for neglected Negro children, and that even temporary placement (especially of children over ten years of age) is "very slow." 64 Overcrowded facilities severely limit the possibilities of adequate temporary placement in institutional homes, ${ }^{65}$ and the effect on the child of institutional placement, though at present very imperfectly understood, can be disastrous. ${ }^{66}$ Under these circumstances, the court deals less with the "best interests" of the neglected child than with his "least bad interests"; the possible utility of taking custody from the parent is minimized. It may be best simply to yield to parental desire for custody, rather than to leave the child in an undesirable and totally foreign cultural environment.

62 See Foster \& Freed, supra note 28, at 622. Foster and Freed assume the presence of an aggressive adversary contest between individuals in custody disputes.

63 Simpson, supra note 2, at 391. Simpson speculates that a sort of "quasi-adoption" classification might produce significant new opportunities for placement, but offers no evidence to support the conjecture. In any event, a new legal status for the child would require a new custody rule tailored to it.

64 Interview with Mr. Patrick J. McNally, Chicago Legal Aid Bureau, Juvenile Court Branch, Oct. 12, 1967.

65 Paulsen, supra note 30, at 386, describes the extent of the problem in New York.

66 Paulsen, id. at 387-88, details the shocking consequences of overcrowding in one major facility. See generally Yarrow, Separation from Parents During Early Childhood, 1 REVIEW OF Chitd DeVELOpMENT RESEARCh 89 (M. \& L. Hoffman ed. 1964), for a discussion of recent thinking and research in the field. 
Moreover, the policy of the neglect statutes is not to break up the family but rather to repair the unsatisfactory home environment and make it possible for the child to remain with the parent. ${ }^{67}$ Non-neglect custody cases involve situations in which the family unit is effectively dissolved, by divorce or voluntary transfer of custody, before the custody question reaches the court, rather than by intervention of welfare agencies in the affairs of the family. In the non-neglect cases, various members of the dissolved family compete for custody of the child, and the court must choose among them. But in neglect cases, the court attempts to cure defects in an unsatisfactory environment, unless it judges those defects incurable and finds the parent unfit to raise the child; the family unit, if viable at all, is not to be destroyed.

Finally, neglect cases deal with a broad spectrum of issues. Some rehearings present problems similar to those encountered at the original neglect proceedings; others, especially those occurring some time after the original hearing, focus on questions of long-term or indefinite placement very close to the issue of permanent custody. Rules framed to deal with the neglect rehearings must be flexible enough to cope with this wide range of situations.

In each neglect case, both the effect on the child of immediate return to the parent, and the extent of the parent's efforts toward rehabilitation, should be reviewed. In general, the greater the rehabilitation efforts the better the child is likely to fare. However, in some cases, other factors may predominate. For example, if the child has been out of the custody of its parents for some time, the court may be compelled to place more weight upon the child's fate than upon the parents' good works. ${ }^{68}$ Or if the child is in an institution a lesser grade of rehabilitation may suffice to gain return of custody.

The present situation of both parent and child should be reviewed not simply to establish the balance of interests between parent and child. Regardless of the mixture of interests between parent and child, the court should consider the possibilities that the parents will

67 ALA. CODE tit. 13, § 361 (1958); DeL. Code ANN. tit. 10, §§ 902, 1102 (1953); D.C. Code ANN. § 16-2308 (1966); Kay \& Philips, supra note 18, at 412 . Of course, there are cases when the child should be taken from the parent, and the courts should be sensitive to the issues characterizing these cases; but the courts should be primarily oriented toward curing defects in the home environment whenever feasible.

68 Courts are in some measure responsive to this issue, both with regard to detailed psychological assessment and as a "common sense" principle, Halstead v. Halstead, 144 N.W.2d 861 (Iowa 1966); Kouris v. Lunn, 257 Iowa 1267, 136 N.W.2d 502 (1965); Painter v. Bannister, 258 Iowa 1390, 140 N.W.2d 152 (1966); Pickens v. Pickens, 186 So. 2d 683 (La. App. 1966); Ogletree v. Crates, 363 S.W.2d 431 (Tex. 1963), Rosson v. DeArman, 323 S.W.2d 75 (Tex. Civ. App. 1959). See generally Yarrow, supra note 66. In extreme cases, postponement of return to the parent might have to be of indefinite duration. 
be-able, in the future, to establish a viable family setting. The issue is not whether family $A$ is better than family $B$, as in the "best interests" approach. Rather the court should concentrate upon the parents who requested the rehearing. Certainly the "other family" situation is relevant. A good custody family may permit the court to delay return of custody in doubtful cases; a bad custody family or an institutional situation may permit acceleration of the child's return. But the court should avoid a simple weighing in the balance. Such a concentration on the child's parents at rehearing does not demand a finding that the family is hopeless, or unfit, in order to deny return of custody. Immediate return of custody may be forestalled if there is a significant possibility of future neglect. Finally, if the proper path is not clear, the traditional preference for the natural parent should decide the case.

A custody rule tailored to these objectives should place the burdens of persuasion at rehearing concerning both the child's welfare and the parents' future conduct on the child welfare agency or other original complainant, rather than on the parent. The original complainant should be asked to persuade the court that the rights of the child, the parents, and society as a whole would be best served by refusing to return custody to the parent. This reversal of the burdens of persuasion is highly desirable in view of the tactical disadvantages faced by the parent. Moreover, it places the duty of establishing the fact issues on the child welfare agency, which has direct access to information about the child's present circumstances and to expert evaluation of the facts.

\section{CoNCLUSION}

The application of a general custody rule to parental petitions for return of neglected children fails to take into account the basic differences between neglect cases and other custody disputes. Furthermore, a general neglect case rule cannot be reconciled with the position of the custody rehearing between the polar questions of original temporary placement and final, permanent disposition of custody. Thus, the "best interests" and "unfit parent" standards are inadequate devices for dealing with this intermediate problem. But the flaws in the two current rules outline the real issues presented in neglect case custody rehearings, and in so doing frame the elements of a more satisfactory approach to the problem. 